\title{
Identification of degradome components associated with prostate cancer progression by expression analysis of human prostatic
}

\section{tissues}

\author{
ACP Riddick ${ }^{1,4}$, CJ Shukla ${ }^{1,2,4}$, CJ Pennington ${ }^{2}$, R Bass ${ }^{2}$, RK Nuttall ${ }^{2}$, A Hogan ${ }^{2}$, KK Sethia', V Ellis ${ }^{2}$, AT Collins ${ }^{3}$, \\ NJ Maitland ${ }^{3}$, RY Ball' and DR Edwards',2 \\ 'Norfolk and Norwich University Hospital NHS Trust, Norwich NR4 7UY, UK; ${ }^{2}$ School of Biological Sciences, University of East Anglia, Norwich NR4 7TJ, \\ UK; ${ }^{3}$ YCR Cancer Research Unit, Department of Biology, University of York, YO 10 5YW, UK
}

\begin{abstract}
Extracellular proteases of the matrix metalloproteinase (MMP) and serine protease families participate in many aspects of tumour growth and metastasis. Using quantitative real-time RT-PCR analysis, we have undertaken a comprehensive survey of the expression of these enzymes and of their natural inhibitors in 44 cases of human prostate cancer and 23 benign prostate specimens. We found increased expression of MMPIO, 15, 24, 25 and 26, urokinase plasminogen activator-receptor (UPAR) and plasminogen activator inhibitor-I (PAII), and the newly characterised serine proteases hepsin and matriptase-I (MTSPI) in malignant tissue compared to benign prostate tissue. In contrast, there was significantly decreased expression of MMP2 and MMP23, maspin, and the protease inhibitors tissue inhibitor of metalloproteinase 3 (TIMP3), TIMP4 and RECK (reversion-inducing cysteine-rich protein with Kazal motifs) in the cancer specimens. The expression of MMPI 5 and MMP26 correlated positively with Gleason score, whereas TIMP3, TIMP4 and RECK expression correlated negatively with Gleason score. The cellular localisation of the expression of the deregulated genes was evaluated using primary malignant epithelial and stromal cell cultures derived from radical prostatectomy specimens. MMPIO and 25, hepsin, MTSPI and maspin showed predominantly epithelial expression, whereas TIMP 3 and 4, RECK, MMP2 and 23, UPAR and PAII were produced primarily by stromal cells. These data provide the first comprehensive and quantitative analysis of the expression and localisation of MMPs and their inhibitors in human prostate cancer, leading to the identification of several genes involved in proteolysis as potential prognostic indicators, in particular hepsin, MTSPI, MMP26, PAII, UPAR, MMPI5, TIMP3, TIMP4, maspin and RECK. British Journal of Cancer (2005) 92, 2 I7I-2180. doi:I0.1038/sj.bjc.6602630 www.bjcancer.com
\end{abstract}

Published online 3I May 2005

(c) 2005 Cancer Research UK

Keywords: matrix metalloproteinases; serine proteases; prostate cancer

Prostate cancer will affect one man in five and is now the leading cause of cancer deaths in Western men (Levi et al, 2004). The biological mechanisms underlying its initiation and progression are incompletely understood and there is an urgent need for the identification of robust prognostic markers, so that the most effective treatment can be provided. For example, the optimum treatment of patients with localised prostate cancer is uncertain and the identification of molecular markers that are predictive of increased malignant potential could make an important contribution to therapeutic decision-making.

Degradation of the extracellular matrix (ECM) is integral in tumorigenesis and is mediated by the activity of ECM proteases, including the matrix metalloproteinases (MMPs) and the serine proteases (Sternlicht and Werb, 2001; Egeblad and Werb, 2002). There are 24 members of the human MMP family (Lopez-Otin and Overall, 2002) that have a number of other roles in tumorigenesis, including a direct role in ECM degradation mediating tumour

\footnotetext{
*Correspondence: DR Edwards; e-mail: dylan.edwards@uea.ac.uk

${ }^{4}$ These authors contributed equally to this work

Received I January 2005; revised 30 March 2005; accepted 28 April

2005; published online 3I May 2005
}

establishment, growth and migration, avoidance of apoptosis, angiogenesis and interaction with the immune system. These effects are achieved in part by the cleavage of growth factors, their receptors, or other growth factor-associated proteins (Egeblad and Werb, 2002). Matrix metalloproteinase activity is regulated at several levels. Activation of most MMPs occurs extracellularly and is mediated by proenzyme cleavage involving other MMPs and serine proteases, in particular the plasminogen activator-plasminogen network (Egeblad and Werb, 2002). An important means of their inhibition is achieved by the binding of the tissue inhibitors of metalloproteases (TIMPs), of which there are four members (Jiang et al, 2002; Baker et al, 2002). In addition, the recently characterised MMP inhibitor, RECK (reversion inducing cysteinerich protein with Kazal motifs) can exert effects on the synthesis, activation and activity of several MMPs (Oh et al, 2001; Sasahara et al, 2002). Members of the serine protease family have been shown to be important in a variety of malignant tumours. In particular, the plasminogen activator system, which mediates cell surface plasmin generation via association of urokinase plasminogen activator (uPA) with its glyco-phosphoinositol-anchored receptor (UPAR), thus leading to degradation of pericellular proteins directly, as well as indirectly through activation of several 
pro-MMPs (Andreasen et al, 2000; Egeblad and Werb, 2002; Ellis, 2003; Freije et al, 2003). Moreover, transmembrane serine proteases (e.g. hepsin and matriptase) have also been implicated in tumorigenesis, but their roles are as yet unresolved (Dhanasekaran et al, 2001; Stamey et al, 2001; Srikantan et al, 2002; Chen et al, 2003; Galkin et al, 2004).

There is considerable evidence supporting the involvement of MMPs and TIMPs in prostate cancer (Pajouh et al, 1991; Lokeshwar et al, 1993; Boag and Young, 1994; Wood et al, 1997; Hashimoto et al, 1998; Still et al, 2000; Srikantan et al, 2002; Trudel et al, 2003; Udayakumar et al, 2003; Zhao et al, 2003). However, research has focused almost entirely on the earlier discovered MMPs (MMP-2, -7 and -9) and TIMP-1 and -2; the more recently discovered MMPs have received little attention (Zhao et al, 2003). Similarly, little is known of the potential roles of the transmembrane serine proteases and their inhibitors. However, recent data from microarray profiling studies have linked hepsin with prostate cancer pathogenesis (Dhanasekaran et al, 2001; Stamey et al, 2001; Ernst et al, 2002; Chen et al, 2003).

In this study we investigated the expression of the entire MMP and TIMP families, RECK, and selected serine proteases and inhibitors in a large collection of primary malignant and nonmalignant prostate tissues. In the absence of monoclonal antibodies of equivalent specificity and sensitivity, we used quantitative real-time PCR assay (Nuttall et al, 2003) to measure mRNA levels. In order to investigate the cellular localisation of these genes, we measured mRNA levels in primary epithelial and stromal cell cultures derived from malignant prostate tissues. These data provide the first detailed descriptions of the stromal $v s$ epithelial origin of the expression of the proteases and inhibitors, and indicate that several proteolysis-associated genes may be useful prognostic indicators in prostate cancer.

\section{MATERIALS AND METHODS}

\section{Clinical samples}

Samples of malignant and nonmalignant human prostate tissue were obtained from the Partners in Cancer Research Tissue Bank, held in the Department of Histopathology at the Norfolk \& Norwich University Hospital (NNUH). Detailed procedures for obtaining informed patient consent, tissue acquisition, and histopathological and molecular quality control and validation have already been described (Riddick et al, 2003). Samples of malignant prostate tissue were collected from patients undergoing radical prostatectomy or channel transurethral resection of the prostate (TURP), and nonmalignant samples were obtained from patients undergoing radical cystoprostatectomy for transitional cell carcinoma of the bladder or TURP for benign prostatic hyperplasia. Gene expression profiling was undertaken in malignant tissue samples from 44 patients with adenocarcinoma of the prostate (four with Gleason scores 5-6, 25 with Gleason score 7, and 15 with Gleason scores 8-10) and in nonmalignant samples from 23 other patients with benign prostatic hyperplasia. The data were further analysed to relate gene expression to increasing Gleason score.

\section{Primary culture of malignant epithelial and stromal cells from adult, human prostate}

Malignant human prostate tissue was obtained, with patient consent, from nine patients (age range 52-68 years) undergoing radical prostatectomy for prostate cancer. One sample was derived from a Gleason grade 6 carcinoma and the remaining specimens from grade 7 tumours. The presence of prostate cancer was confirmed by histological examination of representative fragments. The tissue was prepared as described previously (Collins et al,
2001). Briefly, collagenase digestion released epithelial structures (organoids; glands and ducts), which where subsequently separated from the stromal fraction by repeated unit gravity centrifugation. The stromal cells were routinely cultured in RPMI 1640 medium supplemented with $10 \%$ foetal calf serum (FCS) and the antibiotics penicillin (100 $\mathrm{U} \mathrm{ml}^{-1}$; Invitrogen) and streptomycin $\left(100 \mu \mathrm{g} \mathrm{ml}^{-1}\right.$; Invitrogen). Epithelial cultures were grown in keratinocyte serum-free medium (KSFM; Invitrogen) with antibiotics as above. For RNA extraction, stromal and epithelial primary cell cultures were grown until $70 \%$ confluent and were lysed directly, without trypsinisation.

\section{RNA extraction and reverse transcription}

Total RNA from the prostate tissues was isolated by first homogenising tissues in RNAzol (Biogenesis, Poole, UK) and then by using the Promega SV Total RNA Isolation System (Promega Corporation, USA) to remove DNA and purify the RNA. RNA was resuspended in nuclease free water and concentrations determined by spectrophotometry using a GeneQuant pro RNA/DNA calculator (Amersham Pharmacia Biotech, Buckinghamshire, UK). For the primary cell cultures, total RNA was extracted using an RNeasy mini kit (Qiagen). In total, $1 \mu \mathrm{g}$ of total RNA was reverse transcribed using $2 \mu \mathrm{g}$ random hexamers (Amersham) and $200 \mathrm{U}$ of Superscript II reverse transcriptase (Life Technologies, Paisley, $\mathrm{UK}$ ), according to the supplier's instructions. cDNA was stored at $-20^{\circ} \mathrm{C}$ until used in the PCR reaction.

\section{Quantitative real-time PCR}

For PCR reactions, specific primers and fluorogenic probes for all known human MMP and TIMP genes, RECK, hepsin, matriptase-1 (MTSP1), matriptase-2 (MTSP2), maspin, urokinase-type plasminogen activator $(U P A)$ urokinase-type plasminogen activator receptor $(u P A R)$, hepatocyte growth factor and activator (HGF and $H G F A$ ), and plasminogen activator inhibitor types-1 and -2 (PAI1, PAI2) were designed using Primer Express 1.0 software (PE Applied Biosystems) and synthesised by PE Applied Biosystems; sequences for primers and probes for the serine proteases are given in Table 1 . Where possible, to prevent the amplification of genomic DNA and to ensure that the PCR signal was generated from cDNA, primers were generated with sequences within different exons, close to intron-exon boundaries. BLASTN searches (Altschul et al, 1990) were conducted on all primer/ probe nucleotide sequences to ensure gene specificity. The identity of PCR products was confirmed by direct sequencing of the amplicon. The $18 \mathrm{~S}$ ribosomal RNA gene was used as an endogenous control to normalise for differences in the amount of total RNA in each sample, using previously validated procedures (Wall and Edwards, 2002; Nuttall et al, 2003); 18S rRNA primers and probe were purchased from PE Applied Biosystems. PCR reactions were performed as described (Nuttall et al, 2003), with each reaction containing $5 \mathrm{ng}$ of reverse transcribed RNA in $25 \mu \mathrm{l}$. To determine the relative RNA levels within the samples, standard curves for the PCR reaction were prepared by using the cDNA from one sample and making two-fold serial dilutions covering the range equivalent to $20-0.625 \mathrm{ng}$ of RNA (for $18 \mathrm{~S}$ analyses, the range was $4-0.125 \mathrm{ng}$ ).

\section{Statistical analysis}

The data did not satisfy normality or equal variance, so nonparametric tests were used. The Mann-Whitney $U$ test was carried out to compare malignant and nonmalignant samples. Further tests were carried out using the two-tailed Spearman rank correlation coefficient to determine whether there were associations with the Gleason sum score. Finally, the epithelial and stromal cell culture populations derived from malignant prostate 
Table I Primer-probe sequences of the genes analysed by quantitative RTPCR. Sequences for the primers and probes are shown in $5^{\prime}$ to $3^{\prime}$ orientation

\begin{tabular}{|c|c|}
\hline Gene name & Primer/probe sequence \\
\hline \multicolumn{2}{|l|}{ Hepsin } \\
\hline Forward primer & GAGGAGAACAGCAACGATATTGC \\
\hline Reverse primer & CCCGTCACGGTACAGATCTTG \\
\hline Probe & CTCACAGAATACATCCAGCCTGTGTGCCT \\
\hline \multicolumn{2}{|l|}{ MTSPI } \\
\hline Forward primer & CACCTCAGTGGTGGCTTTCC \\
\hline Reverse primer & GCGTGCAGGCCAAAGCT \\
\hline Probe & CAAAACAGTACAGAGGACCCAGGACAACAGC \\
\hline \multicolumn{2}{|l|}{ MTSP2 } \\
\hline Forward primer & CAGAAGATGCTCAAGGAGCTCAT \\
\hline Reverse primer & GGAATAGACGGAGCTGGAGTTG \\
\hline Probe & ACCAGCACCCGCCTGGGAACTTACT \\
\hline \multicolumn{2}{|l|}{ Maspin } \\
\hline Forward primer & CAGATGGCCACTTTGAGAACATT \\
\hline Reverse primer & GGCAGCATTAACCACAAGGATT \\
\hline Probe & GGCAGCATTAACCACAAGGATT \\
\hline \multicolumn{2}{|l|}{ UPA } \\
\hline Forward primer & TGGAACTCTGCCACTGTCCTT \\
\hline Reverse primer & GGCCCACCTGCACATAGC \\
\hline Probe & ATAATTACTGCAGGAACCCAGACAACCGGA \\
\hline \multicolumn{2}{|l|}{ UPAR } \\
\hline Forward primer & GCCCAATCCTGGAGCTTGA \\
\hline Reverse primer & TTCCCCTTGCAGCTGTAACAC \\
\hline Probe & CTGCCGCAGAATGGCCGCC \\
\hline \multicolumn{2}{|l|}{ PAll } \\
\hline Forward primer & CAGAGGTGGAGAGAGCCAGATT \\
\hline Reverse primer & CTGGTCCACGGCTCCTTTC \\
\hline Probe & GTGAAGACACACACAAAAGGTATGATCAGCAACTT \\
\hline \multicolumn{2}{|l|}{ PAl2 } \\
\hline Forward primer & AGTGTCAATAAGCTGTTTGGTGAGA \\
\hline Reverse primer & TCTAGCTTCTTCTGCACATTCTAGGA \\
\hline Probe & CTTCCGGGAAGAATATATTCGACTCTGTCAGAAA \\
\hline \multicolumn{2}{|l|}{ TPA } \\
\hline Forward primer & AAACCCAGATCGAGACTCAAAGC \\
\hline Reverse primer & GGCTGACCCATTCCCAAAG \\
\hline Probe & СCTGCCTGCTCTGAGGGAAACAGTGAC \\
\hline \multicolumn{2}{|l|}{ PSA } \\
\hline Forward primer & TCTGCGGCGGTGTTCTG \\
\hline Reverse primer & CTGTGCCGACCCAGCAA \\
\hline Probe & CCACTGCATCAGGAACAAAAGCGTGAT \\
\hline \multicolumn{2}{|l|}{ HGFA } \\
\hline Forward primer & CATCGAGAAGTACATCCCGTACAC \\
\hline Reverse primer & CAGATGGGCTGCACGAACT \\
\hline Probe & CCAGCGACCACGACCTCGTCCT \\
\hline \multicolumn{2}{|l|}{ HAll } \\
\hline Forward primer & CGCGGCATCTCCAAGAAG \\
\hline Reverse primer & AGCCTGTGCTGGGAATGG \\
\hline Probe & TGTGTTTGGCCTGAGGCGGGA \\
\hline \multicolumn{2}{|l|}{ HAl2 } \\
\hline Forward primer & GCTCTGAGGAGGCCTGCAT \\
\hline Reverse primer & AAGAGGATCAACACCATCACGAA \\
\hline Probe & CTCCGCTGCTTCCGCCAGCA \\
\hline
\end{tabular}

Probes contain an FAM fluorescent reporter on the $5^{\prime}$ end and a TAMRA quencher on the $3^{\prime}$ end. Primer-probe combinations for TIMP and RECK genes have been described elsewhere (Nuttall et al, 2003). For the MMPs and TIMPs, primer and probe sequences are the property of Applied Biosystems (Warrington, UK). HGFA $=$ HGF activator samples were also compared using the nonparametric MannWhitney $U$-test. For all tests, a $P$-value of less than 0.05 was considered statistically significant.

\section{RESULTS}

Expression of proteases and inhibitors in surgical specimens of prostate tissue

Our tissue banking technique and quality assurance procedures have been described in detail (Riddick et al, 2003). Briefly, a 9-mm

Table 2 Summary of expression profiling of genes showing differential expression between benign and malignant tissues, and relationships with Gleason score

\begin{tabular}{|c|c|c|c|}
\hline Gene & $\begin{array}{c}\text { Malignant vs } \\
\text { non-malignant }\end{array}$ & $\begin{array}{l}\text { Correlation with } \\
\text { Gleason score }\end{array}$ & $\begin{array}{l}\text { Direction of } \\
\text { change in } \\
\text { malignancy }\end{array}$ \\
\hline MMPI & $P=0.911$ & $P=0.533$ & \\
\hline MMP2 & $P=0.004$ & $P=0.028 / R=-0.286$ & $\downarrow$ \\
\hline MMP3 & $P=0.835$ & ND & \\
\hline MMP7 & $P=0.106$ & NS & \\
\hline MMP8 & $N / D$ & ND & \\
\hline MMPQ & $P=0.501$ & ND & \\
\hline MMPIO & $P=0.016$ & $P=0.015 / R=-0.297$ & $\uparrow$ \\
\hline MMPII & $P=0.539$ & ND & \\
\hline MMPI2 & $P=0.883$ & ND & \\
\hline MMPI3 & $N / D$ & ND & \\
\hline MMPI4 & NS & NS & \\
\hline MMPI5 & $P<0.0001$ & $P<0.000 I / R=0.484$ & $\uparrow$ \\
\hline MMPI6 & NS & NS & \\
\hline MMPI7 & NS & NS & \\
\hline MMPI9 & $P=0.932$ & ND & \\
\hline MMP20 & N/D & ND & \\
\hline MMP2I & $P=0.288$ & ND & \\
\hline MMP23 & $P<0.0001$ & $P<0.000 \mathrm{I} / R=-0.497$ & $\downarrow$ \\
\hline MMP24 & $P=0.014$ & $P=0.01 I / R=0.289$ & $\uparrow$ \\
\hline MMP25 & $P=0.003$ & NS & $\uparrow$ \\
\hline MMP26 & $P<0.000 I$ & $P<0.000 I / R=0.507$ & $\uparrow$ \\
\hline MMP27 & N/D & ND & \\
\hline MMP28 & $P=0.736$ & ND & \\
\hline TIMPI & $P=0.183$ & ND & \\
\hline TIMP2 & $P=0.126$ & ND & \\
\hline TIMP3 & $P=0.001$ & $P<0.000 I / R=-0.430$ & $\downarrow$ \\
\hline TIMP4 & $P=0.004$ & $P<0.000 I / R=-0.4 I I I$ & $\downarrow$ \\
\hline RECK & $P<0.0001$ & $P<0.000 I / R=-0.423$ & $\downarrow$ \\
\hline Hepsin & $P<0.0001$ & $P<0.0001 / R=0.677$ & $\uparrow$ \\
\hline MTSPI & $P<0.0001$ & $P<0.000 I / R=0.496$ & $\uparrow$ \\
\hline MTSP2 & $P=0.052$ & NS & \\
\hline PSA & $P=0.702$ & NS & \\
\hline HGFA & $P=0.424$ & NS & \\
\hline TPA & $P=0.054$ & NS & \\
\hline uPA & $P=0.04$ & $P=0.706 / R=0.047$ & $\uparrow$ \\
\hline uPAR & $P=0.42$ & $P=0.014 / R=0.290$ & $\uparrow$ \\
\hline PAII & $P=0.001$ & $P=0.004 / R=0.35$ & $\uparrow$ \\
\hline PAI2 & $P=0.032$ & $P=0.028 / R=-0.253$ & $\downarrow$ \\
\hline Maspin & $P<0.001$ & $P<0.000 \mathrm{I} / R=-0.455$ & $\downarrow$ \\
\hline HAll & $P=0.076$ & NS & \\
\hline HAI2 & $P=0.166$ & $P=0.015 / R=-0.279$ & $\downarrow$ \\
\hline
\end{tabular}

Arrows in the right-hand column illustrate direction of change in gene expression with malignancy. $N / D=$ not detected, $N S=$ not significant, $N D=$ not done. The values given are derived from TaqMan expression data after normalisation to I8SrRNA levels, and are probe and, therefore, gene-specific. Comparison of expression between genes is therefore not possible. The statistical test used was the Mann-Whittney $U$ test to compare malignant and non-malignant samples and the two-tailed Spearman rank correlation test. HGFA $=$ HGF activator. Genes showing statistically significant differences are indicated in bold. 

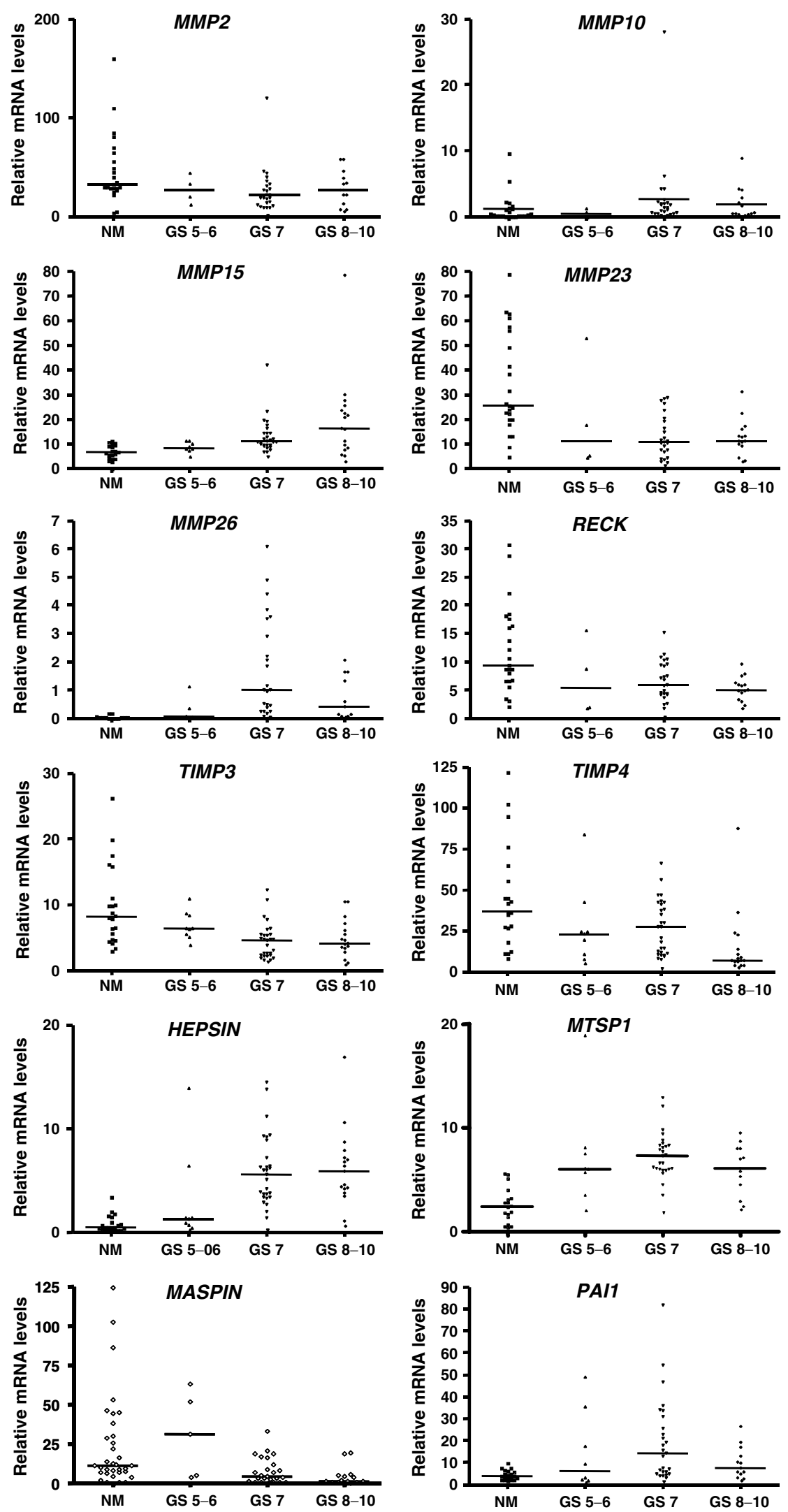

Figure I Quantitative RT-PCR analysis of selected genes showing differential expression in benign vs malignant prostate tissues. Prostate tissue specimens were sorted by Gleason Score (GS), and grouped as those with scores of 5-6, 7 or $8-10$. The values of gene output are after normalisation to I 8SrRNA and are probe, and therefore gene specific, thus precluding comparison of expression between genes. For summary of statistics see Table 2. 
Table 3 Analysis of gene expression in primary epithelial and stromal fibroblast cell cultures from prostate tumours

\begin{tabular}{|c|c|c|c|}
\hline Gene & Epithelial & Stromal & P-value \\
\hline \multicolumn{4}{|c|}{ Gene expressed predominantly by malignant epithelial cell cultures } \\
\hline MMP 10 & l & 0.01 & 0.009 \\
\hline MT6MMP & 1 & 0.09 & 0.009 \\
\hline Hepsin & । & 0 & 0.04 \\
\hline MTSPI & 1 & 0.01 & 0.008 \\
\hline Maspin & 1 & 0 & 0.009 \\
\hline cMet & । & 0.28 & 0.029 \\
\hline HAll & 1 & 0.05 & 0.029 \\
\hline$H A I 2$ & I & 0.03 & 0.029 \\
\hline \multicolumn{4}{|c|}{ Gene expressed predominantly by stromal cell cultures } \\
\hline MMP2 & l & 6.49 & 0.009 \\
\hline MMP23 & 1 & 21.44 & 0.009 \\
\hline TIMP3 & 1 & 15.22 & 0.009 \\
\hline TIMP4 & । & 7.6 & 0.047 \\
\hline RECK & 1 & 50 & 0.009 \\
\hline UPAR & 1 & 5.28 & 0.016 \\
\hline PAll & । & 14.37 & 0.028 \\
\hline$H G F$ & 1 & 1425 & 0.029 \\
\hline \multicolumn{4}{|c|}{ Genes showing no significant difference in expression between cell cultures } \\
\hline MMP26 & 0.566 & 0.25 & 0.175 \\
\hline MMP/5 & $1.07 \mid$ & 0.702 & 0.602 \\
\hline MMP24 & 0.605 & 22.435 & 0.076 \\
\hline UPA & 48.388 & 5.168 & 0.076 \\
\hline HGFA & l & । & । \\
\hline
\end{tabular}

The values given are derived from TaqMan expression data after normalisation to I8SrRNA levels, and are probe and, therefore, gene-specific. Comparison of expression between genes is not possible. All epithelial values have an arbitrarily fixed value of $\mathrm{I}$ and the stromal expression relative to this is shown. The statistical test used was the Mann-Whittney U-test.

punch was used to remove a cylindrical core of tissue from the transversely sliced prostate gland. The core was divided into four quadrants prior to banking by snap freezing in isopentane supercooled in liquid nitrogen. The histopathology of tissue at the circumference of the remaining prostate from which the punch was removed was used to predict the histopathology of the banked tissue as previously validated (Riddick et al, 2003). Our expression profiling strategy has focussed on secreted proteases and their inhibitors, including 28 genes that encompass the entire human MMP and TIMP families, as well as the novel MMP inhibitor $R E C K$. In addition, we have assessed the expression of the components of the plasminogen activation system and the novel transmembrane serine proteases, hepsin, MTSP1 and MTSP2, the inhibitors PAI1, PAI2 HAI1, HAI2 and the serpin-related protein, maspin. The serine proteases, prostate-specific antigen (PSA), $H G F A$ and $t P A$ were also included for the purpose of comparison.

The complete data set of the RNA expression levels of protease and inhibitor genes in benign and malignant human prostate tissues is shown in Table 2 and data for selected genes are shown in Figure 1. An overall comparison of malignant prostate tissues with nonmalignant tissue samples obtained from prostates with BPH revealed that gene expression levels of several MMPs and serine proteases were significantly higher in the malignant samples. These proteases include MMP10, 15, 24, 25 and 26, hepsin, MTSP1, $U P A R$ and also the inhibitor PAI1. By contrast, the levels of expression of $M M P 2$ and MMP23 were significantly lower in the malignant samples, as were the inhibitors TIMP3, TIMP4, RECK, and the serpin-related gene maspin. No significant difference was seen between malignant and BPH samples for the expression of the remaining members of the MMP family.

The data were further analysed to correlate gene expression to increasing Gleason score (Gleason and Mellinger, 1974). Using the Spearman correlation coefficient, we identified statistically sig- nificant positive correlations with Gleason score for $M M P 10,15,24$ and 26, and hepsin, MTSP1, UPAR and PAI1 when comparing the increasing grades to benign or BPH controls (Table 2). In contrast, there were statistically significant negative correlations for MMP2, MMP23, maspin, TIMP3, TIMP4 and RECK.

\section{Comparison of gene expression between primary stromal} and epithelial cells cultured from malignant prostates

Components of protease networks are frequently produced as a host stromal response to the presence of malignant tumour cells in human neoplasms. Thus, in order to define the cellular origins of the proteases identified from the comprehensive gene expression profile from bulk prostate tissue specimens, we undertook analysis of primary cultures of epithelial and stromal cells from radical prostatectomy tissues. Gene expression profiling of the primary malignant epithelial and stromal cell types showed the statistically significant and predominantly epithelial expression of MMP10 and 25, hepsin, MTSP1 and maspin (Table 3; Figure 2). By contrast, there was a significantly greater expression of TIMP3, TIMP4, RECK, MMP2, and 23, UPAR and PAII in stromal cells compared to their epithelial counterparts. There were no significant differences in the levels of gene expression in the epithelial and stromal cells for $M M P 15,24$ and 26.

\section{DISCUSSION}

This study is the first comprehensive analysis of the expression of the entire MMP and TIMP families in a large series of human prostate tissue samples, including both malignant (adenocarcinomatous) and nonmalignant (hyperplastic) tissue. In addition, the differential expression of members of the serine protease family emphasises the importance of evaluating more broadly the components of the 'degradome' - the repertoire of proteases, their inhibitors and associated molecules that each tissue deploys (Lopez-Otin and Overall, 2002). Our data identify several degradome genes as being differentially expressed, suggesting roles in prostate tumorigenesis or as markers of prognosis. The observations on fresh-frozen tissue samples have been extended by analysis of primary cell cultures of prostatic adenocarcinoma cells and stromal cells from the same neoplasms.

\section{Matrix metalloproteinases}

Of the MMPs studied, the greatest increase ( $\sim 30$ fold) in expression levels in malignant compared to nonmalignant prostate tissues was found for MMP26. The expression of MMP26 was also found to correlate strongly with Gleason score, indicating its potential as a prognostic marker in prostate carcinoma. MMP26 has only recently been implicated in tumorigenesis compared to some of the earlier discovered MMPs, and its expression has been found to be elevated in various epithelial neoplasms (Marchenko et al, 2001). Indeed, Zhao et al (2003) have demonstrated elevated expression in prostate cancer by immunohistochemical analysis of a limited number of human specimens. Their findings are consistent with the data presented in this study. The same authors also reveal a mechanism of action for MMP-26 by demonstrating its ability to activate pro-MMP-9 in ARCaP cells. In other studies, Zhao et al (2004) showed that MMP-26 is important in the activation of MMP-9 in breast carcinomas, where its activity is inhibited by TIMPs- 2 and -4 , suggesting that the interplay between these factors may be a significant determinant of malignancy in both breast and prostate neoplasia.

Two MMPs (MMP2 and MMP23) were downregulated in prostate cancer. There is growing recognition that MMPs can exert inhibitory effects on tumour growth, potentially through the generation of angiogenesis inhibitors such as endostatin and 

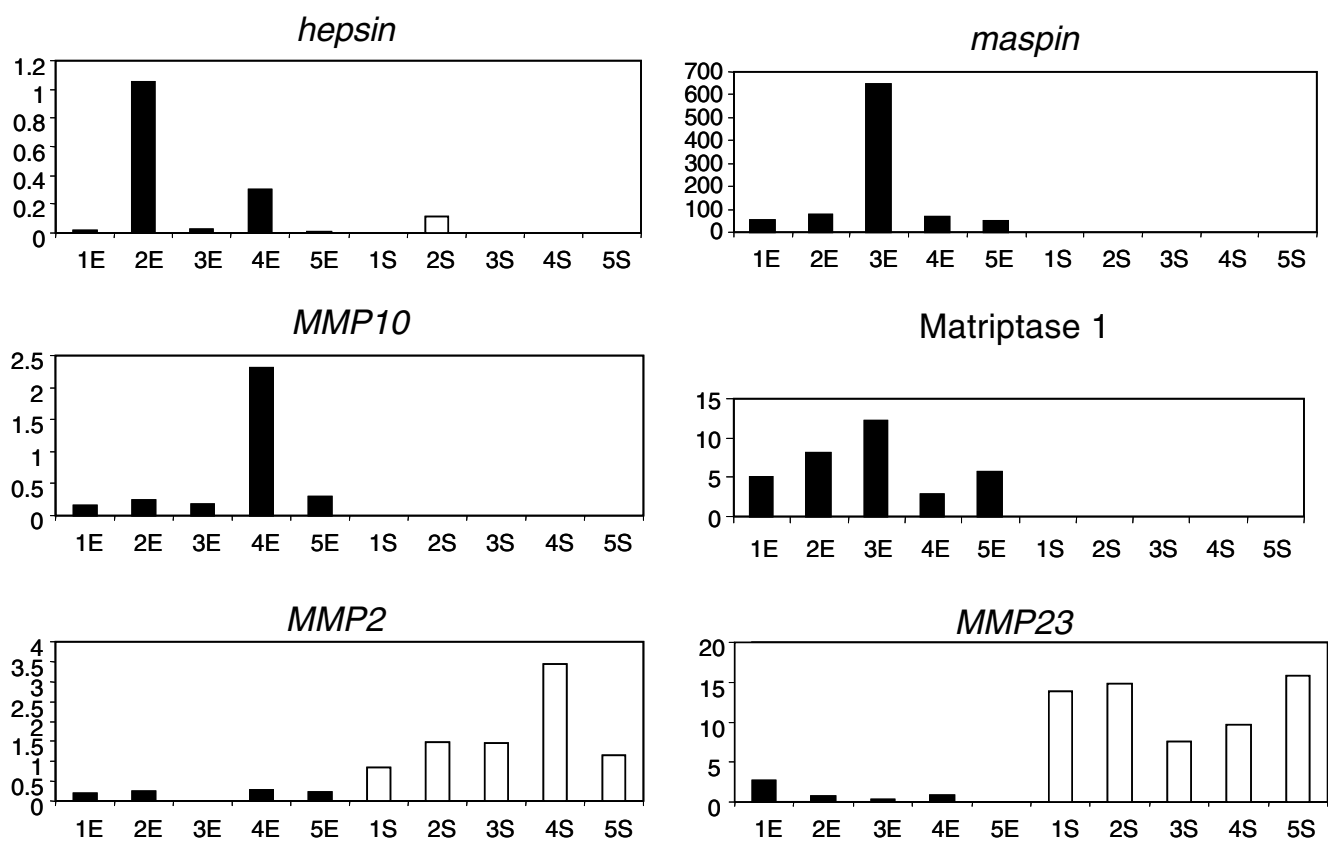

TIMP3
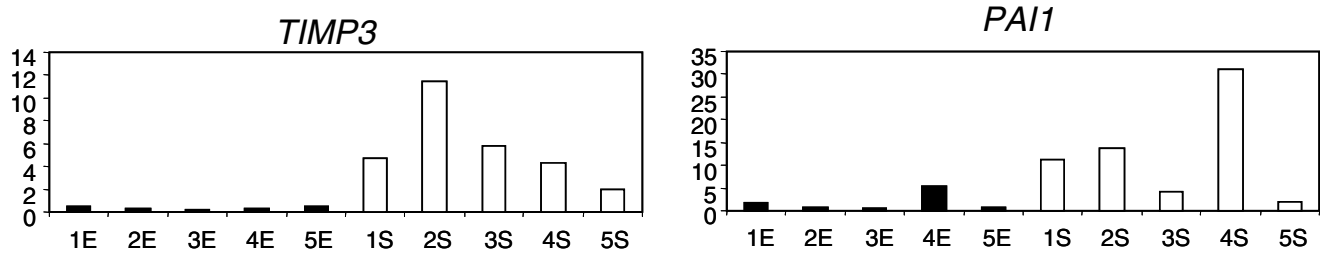

Figure 2 Differential expression of proteases in epithelium or stroma in primary prostate cell cultures. The figure shows QRT-PCR analysis of levels of expression of selected genes in epithelial (black columns) and stromal (white columns) primary cell cultures from human prostate tumours. Genes with a primarily epithelial pattern include hepsin, maspin, MTSPI (matriptase-I) and MMPIO, whereas stromally expressed genes are MMP2, MMP23, TIMP3 and PAII. The values of gene output are after normalisation to I8SrRNA and are probe, and therefore gene specific, thus precluding comparison of expression between genes. For summary of statistics see Table 3 .

tumstatin by cleavage of ECM components (Kalluri, 2003; Lafleur et al, 2003). Also, the absence of an MMP can promote tumorigenesis, as shown by the enhanced susceptibility to skin carcinogenesis displayed by $M m p 8$-null mice (Balbin et al, 2003). It is not clear at present whether MMP2 and 23 might fulfill such a role in prostate tumorigenesis, though their downregulated expression suggests this as a possibility that warrants further study.

Our data for MMP2 are consistent with those of Lichtinghagen et al (2002), who studied the expression of MMP2 in human prostate tissues using quantitative RT-PCR, but differ from observations of MMP-2 protein levels using immunohistochemistry, where levels were increased in prostate cancer tissues (Brehmer et al, 2003), and from a study that identified an increase in transcript level in the highest grades of cancer (Still et al, 2000). Elevated plasma MMP-2 activity has also been suggested to be prognostic for prostate cancer metastasis (Morgia et al, 2005), indicating that there may be a discrepancy between MMP2 RNA and protein levels in prostate tumours. However, the precise spatial expression of $M M P 2$ and its activators and potential substrates will determine its role in disease pathogenesis, and are likely be of more significance than its global level of expression.

To date, there are no data concerning expression of membranebound MMP-23 at the protein level. Elevation of three membranetype-MMPs (MT-MMPs) was also demonstrated in this study, namely MMP15, MMP24 and MMP25 (MT2-, MT5- and MT6$M M P s)$. These MT-MMPs can post-translationally activate pro-
MMP-2 (Llano et al, 1999; Nie and Pei, 2003). They also display intrinsic proteolytic activity towards ECM molecules, which is independent of MMP-2 activation. These proteases could thus participate directly in prostate tumour invasion, and in this regard it is important to note that MMP25 (MT6-MMP) is primarily expressed by the epithelial cancer cells rather than stromal cells. This was also the case for MMP10, which likewise showed elevated expression in prostate cancer epithelium. Of note, Ernst et al (2002) found no difference in expression of MMP10 between total biopsies of benign and malignant prostate tissue. However, comparison of microdissected malignant epithelium with benign epithelium revealed a marked elevation of $M M P 10$ in the malignant cell population. This may explain why we found a modest increase in MMP10 in the malignant samples, but were unable to determine which Gleason grade was responsible for the increase. Other studies have observed MMP10 upregulation in oesophageal carcinomas (Mathew et al, 2002), recurrent lung carcinomas (Cho et al, 2004) and in gliomas (Thorns et al, 2003), where they predict a more malignant phenotype. Similarly, Van Themsche et al (2004) found that induction of MMP10 expression in lymphoma cell lines promoted their malignant phenotype.

\section{TIMPs}

The tissue inhibitors of metalloproteinases, which act as key regulators of the MMPs, have important roles in tumorigenesis. The expression of TIMP3 and TIMP4 decreased progressively with increasing Gleason score, supporting the classic notion that these 
inhibitors may be protective in tumour progression. Therefore, reduced levels of expression of TIMP 3 in this study verifies the findings of Stamey et al (2001), who identified reduced levels of TIMP3 expression by microarray analysis (in prostate tumour samples compared with benign prostatic hyperplasia) and those of Yamanaka et al (2003) who found hypermethylation of the TIMP3 gene promoter (resulting in repressed expression). The mechanisms of action for the TIMPs vary between members, with some displaying growth promoting and antiapoptotic effects in some tumour contexts. In addition, there is evidence for effects that are independent of MMP inhibition. TIMP-3, which emerges as one of the most consistently tumour inhibitory TIMPs, can promote apoptosis by its selective effects on A Disintegrin And Metalloproteinase (ADAM)-mediated shedding of death-domain containing receptors (Ahonen et al, 2003). Independent of its MMP inhibitory activity, TIMP-3 suppresses angiogenesis by blocking the interaction of VEGF with VEGFR-2 (Qi et al, 2003). On the other hand, TIMP-4 can either promote (Jiang et al, 2001; Tunuguntla et al, 2003) or inhibit tumour progression, depending on the nature of the tumour and mode of delivery (Wang et al, 1997; Celiker et al, 2001; Groft et al, 2001; Zhao et al, 2004).

TIMP1 and TIMP 2 expression on the other hand was not altered in our study. There have been previous studies demonstrating both elevated (Hashimoto et al, 1998) and reduced levels of expression (Lokeshwar et al, 1993; Brehmer et al, 2003) of these genes using semiquantitative methods of analysing gene expression. Clearly, further studies are required, particularly in view of the emerging theme of TIMP-1 supporting tumour progression in lymphomas (Guedez et al, 1998; Kossakowska et al, 2000; Oelmann et al, 2002; Kuittinen et al, 2003; Liu et al, 2003), colorectal carcinoma (Holten-Andersen et al, 2005), carcinoma of the breast (Lee et al, 2003; Porter et al, 2004), and skin tumorigenesis (Rhee et al, 2004). RECK, a novel metalloprotease inhibitor, is tentatively thought to limit tumour progression by inhibition of MMPs-2, -9 and -14 (each of which affects angiogenesis). Downregulation of RECK was seen with increasing Gleason score, similar to TIMP3 and TIMP4. Notably, TIMP3, TIMP4 and RECK were all expressed predominantly by stromal cells. We considered whether the decreased expression of these stromally expressed genes (and also MMPs-2 and -23) in cancers compared to benign tissues might reflect a change in the proportion of epithelial to stromal cells due to expansion of the malignant epithelial compartment. However, other genes that show a stromal expression pattern did not show the same reduction, for instance, PAI1 and $U P A R$ are elevated (see below) and $H G F$, also stromal in origin (data not shown) was unaltered in overall expression between benign and malignant tissues. Thus, we argue that the proportion of stromal cells in the prostate tissue homogenates does not vary appreciably between benign and malignant tissues, and therefore the reduced expression of TIMP3, TIMP4 and RECK is most likely a functional consequence of tumour-stromal interactions.

\section{Serine proteases and inhibitors}

Serine proteases of the uPA/plasminogen/plasmin cascade have been implicated in prostate cancer progression, where they may act independently or may activate MMPs. Our data show elevated transcript levels of PAI1 and $U P A R$ in cancer compared to benign tissues, with no significant changes in expression of $u P A$ mRNA levels. Interestingly soluble uPAR (suPAR) levels are elevated in the serum of prostate cancer patients (Miyake et al, 1999; McCabe et al, 2000). It is likely therefore that the increased $u P A R$ mRNA expression that we observe in prostate stromal cells at least partially underpins these increases. As with the TIMPs, the role of PAI1 in malignancy may be paradoxical, since in some models it promotes tumour invasion and angiogenesis. Moreover, elevated expression of PAI1 has also been seen in lung, breast and ovarian carcinomas (Robert et al, 1999; Pedersen et al, 2000; Salden et al,
2000; Borgfeldt et al, 2001). PAI1 has effects both on cell adhesion and plasmin activation (Czekay and Loskutoff, 2004), and thus both the extent and location of its expression in relation to its interaction partners will determine its net contribution to malignancy. Ours are the first data to demonstrate elevated expression of PAI1 in prostate cancer, and given current knowledge of the biology of PAI1, it is likely that it is relevant for the promotion of cell invasion or tumour vascularisation.

Our data identify the transmembrane serine proteases hepsin and matriptase-1 (MTSP1) as potentially strong prognostic markers of prostate cancer. The marked elevation of hepsin in malignant prostate tissues and correlation with increasing Gleason score were in agreement with other data from microarray analyses and real-time PCR studies (Dhanasekaran et al, 2001; Stamey et al, 2001; Ernst et al, 2002; Chen et al, 2003; Riddick et al, 2003; Stephan et al, 2004). The functional importance of hepsin has been shown by its overexpression in a transgenic mouse model of prostate tumorigenesis, which led to basement membrane disorganisation and enhanced metastasis (Klezovitch et al, 2004). Elevated expression of MTSP1 in prostate cancer tissues and positive correlation with increasing Gleason score are also novel findings. The cell culture data indicate that its expression is predominantly epithelial in origin, which is in keeping with other tumour systems such as lung mesotheliomas (Hoang et al, 2004), ovarian (Oberst et al, 2002), breast (Lin et al, 1997; Takeuchi et al, 1999; Oberst et al, 2001) and in epithelial tissues in general (Oberst et al, 2003). Recent data have indicated that matriptase may have a role in the activation of hepatocyte growth factor (Lee et al, 2000) and it will be of interest to determine whether this is integral to its action in the prostate, where there is evidence for participation of increased HGF-Met signalling in tumour progression (You et al, 2003; Hall et al, 2004). Met and matriptase are epithelial in origin, whereas HGF is stromally derived, thus supporting the importance of epithelial-stroma interaction in tumorigenesis (Lee et al, 2000).

Maspin, which has been shown to have tumour-suppressive effects, was found to be downregulated in prostate cancer tissues in agreement with Chen et al (2003). Members of our group have shown that maspin is not functional as a serine protease inhibitor (Bass et al, 2002), which has now been confirmed at the structural level (Al Ayyoubi et al, 2004), where it has been shown that the reactive centre loop necessary for inhibitory function is maintained in a highly constrained, inactive conformation. Its tumour suppressive effects are likely due to other mechanisms, including promotion of cell adhesive mechanisms, as shown by Abraham et al (2003) where TRAMP C2N cells stably transfected with maspin exhibited a lower tumorigenicity demonstrated by a reduced growth rate, decreased metastatic potential and increased adhesiveness to fibronectin and laminin. In another model, Cher et al (2003) found that maspin inhibits osteolysis, tumour growth and angiogenesis.

\section{CONCLUSION}

Our comprehensive survey has identified components of the degradome as potential markers of prostate carcinoma. These data identify MMP2, MMP10, MMP15, MMP26, MMP23, TIMP3, TIMP4, hepsin, MTSP1, PAI1, UPAR and maspin as genes that require further study at the protein level and via immunohistochemical analysis to elucidate their contributions to prostate cancer progression. The metalloproteinase and serine proteinase pathways are not independent of each other and, indeed, converge at the pericellular environment to mediate the proteolysis, which potentially facilitates invasion of the ECM and other structures by cancer cells. This study points towards future research avenues to elucidate these interactions and to establish their relevance in human prostate cancer. 


\section{ACKNOWLEDGEMENTS}

This work was supported by the Big C Appeal, the British Urology Foundation, the Prostate Research Campaign, the Royal Colleges of Surgeons of England and Edinburgh, the Medical Research
Council, the Mason Medical Foundation, the Stuart Williams Charitable Trust, Yorkshire Cancer Research and European Union Framework 6 LSHC-CT-2003-503297. We are grateful to Mr I Sheriffs and colleagues in the Department of Histopathology at NNUH for their expertise in tissue banking.

\section{REFERENCES}

Abraham S, Zhang W, Greenberg N, Zhang M (2003) Maspin functions as tumor suppressor by increasing cell adhesion to extracellular matrix in prostate tumor cells. J Urol 169: 1157-1161

Ahonen M, Poukkula M, Baker AH, Kashiwagi M, Nagase H, Eriksson JE, Kahari VM (2003) Tissue inhibitor of metalloproteinases-3 induces apoptosis in melanoma cells by stabilization of death receptors. Oncogene 22: $2121-2134$

Al Ayyoubi M, Gettins PG, Volz K (2004) Crystal structure of human maspin, a serpin with anti-tumor properties: maspin's reactive center loop is exposed but constrained. J Biol Chem 279: 55540-55544

Altschul SF, Gish W, Miller W, Myers EW, Lipman DJ (1990) Basic local alignment search tool. J Mol Biol 215: $403-410$

Andreasen PA, Egelund R, Petersen HH (2000) The plasminogen activation system in tumor growth, invasion, and metastasis. Cell Mol Life Sci 20(57): $25-40$

Baker AH, Edwards DR, Murphy G (2002) Metalloproteinase inhibitors: biological actions and therapeutic opportunities. J Cell Sci 115: 3719-3727

Balbin M, Fueyo A, Tester AM, Pendas AM, Pitiot AS, Astudillo A, Overall CM, Shapiro SD, Lopez-Otin C (2003) Loss of collagenase-2 confers increased skin tumor susceptibility to male mice. Nat Genet 35: $252-257$

Bass R, Fernandez AM, Ellis V (2002) Maspin inhibits cell migration in the absence of protease inhibitory activity. J Biol Chem 277: 46845-46848

Boag AH, Young ID (1994) Increased expression of the 72-kd type IV collagenase in prostatic adenocarcinoma. Demonstration by immunohistochemistry and in situ hybridization. Am J Pathol 144: 585-591

Borgfeldt C, Hansson SR, Gustavsson B, Masback A, Casslen B (2001) Dedifferentiation of serous ovarian cancer from cystic to solid tumors is associated with increased expression of mRNA for urokinase plasminogen activator (UPA), its receptor (UPAR) and its inhibitor (PAI-1). Int J Cancer 92: 497 - 502

Brehmer B, Biesterfeld S, Jakse G (2003) Expression of matrix metalloproteinases (MMP-2 and -9) and their inhibitors (TIMP-1 and -2) in prostate cancer tissue. Prostate Cancer Prostatic Dis 6: 217-222

Celiker MY, Wang M, Atsidaftos E, Liu X, Liu YE, Jiang Y, Valderrama E, Goldberg ID, Shi YE (2001) Inhibition of Wilms' tumor growth by intramuscular administration of tissue inhibitor of metalloproteinases-4 plasmid DNA. Oncogene 19(20): $4337-4343$

Chen Z, Fan Z, McNeal JE, Nolley R, Caldwell MC, Mahadevappa M, Zhang Z, Warrington JA, Stamey TA (2003) Hepsin and maspin are inversely expressed in laser capture microdissectioned prostate cancer. J Urol 169: $1316-1319$

Cher ML, Biliran Jr HR, Bhagat S, Meng Y, Che M, Lockett J, Abrams J, Fridman R, Zachareas M, Sheng S (2003) Maspin expression inhibits osteolysis, tumor growth, and angiogenesis in a model of prostate cancer bone metastasis. Proc Natl Acad Sci USA 100: 7847-7852

Cho NH, Hong KP, Hong SH, Kang S, Chung KY, Cho SH (2004) MMP expression profiling in recurred stage IB lung cancer. Oncogene 23: $845-851$

Collins AT, Habib FK, Maitland NJ, Neal DE (2001) Identification and isolation of human prostate epithelial stem cells based on alpha(2)beta(1)-integrin expression. J Cell Sci 114: 3865-3872

Czekay RP, Loskutoff DJ (2004) Unexpected role of plasminogen activator inhibitor 1 in cell adhesion and detachment. Exp Biol Med (Maywood) 229: 1090 - 1096

Dhanasekaran SM, Barrette TR, Ghosh D, Shah R, Varambally S, Kurachi K, Pienta KJ, Rubin MA, Chinnaiyan AM (2001) Delineation of prognostic biomarkers in prostate cancer. Nature 412: $822-826$

Egeblad M, Werb Z (2002) New functions for the matrix metalloproteinases in cancer progression. Nat Rev Cancer 2: $161-174$

Ellis V (2003) Plasminogen activation at the cell surface. Current Topics in Dev Biol 54: $263-312$
Ernst T, Hergenhahn M, Kenzelmann M, Cohen CD, Bonrouhi M, Weninger A, Klaren R, Grone EF, Wiesel M, Gudemann C, Kuster J, Schott W, Staehler G, Kretzler M, Hollstein M, Grone HJ (2002) Decrease and gain of gene expression are equally discriminatory markers for prostate carcinoma: a gene expression analysis on total and microdissected prostate tissue. Am J Pathol 160: 2169-2180

Freije JM, Balbin M, Pendas AM, Sanchez LM, Puente XS, Lopez-Otin C (2003) Matrix metalloproteinases and tumor progression. Adv Exp Med Biol 532: $91-107$

Galkin AV, Mullen L, Fox WD, Brown J, Duncan D, Moreno O, Madison EL, Agus DB (2004) CVS-3983, a selective matriptase inhibitor, suppresses the growth of androgen independent prostate tumor xenografts. Prostate 61: $228-235$

Gleason DF, Mellinger GT (1974) Prediction of prognosis for prostatic adenocarcinoma by combined histological grading and clinical staging. $J$ Urol 111: $58-64$

Groft LL, Muzik H, Rewcastle NB, Johnston RN, Knauper V, Lafleur MA, Forsyth PA, Edwards DR (2001) Differential expression and localization of TIMP-1 and TIMP-4 in human gliomas. Br J Cancer 85: 55-63

Guedez L, Stetler-Stevenson WG, Wolff L, Wang J, Fukushima P, Mansoor A, Stetler-Stevenson M (1998) In vitro suppression of programmed cell death of B cells by tissue inhibitor of metalloproteinases-1. J Clin Invest 102: $2002-2010$

Hall CL, Tsan R, Mugnai G, Mazar A, Radinsky R, Pettaway CA (2004) Enhanced invasion of hormone refractory prostate cancer cells through hepatocyte growth factor (HGF) induction of urokinase-type plasminogen activator (u-PA). Prostate 59: $167-176$

Hashimoto K, Kihira Y, Matuo Y, Usui T (1998) Expression of matrix metalloproteinase-7 and tissue inhibitor of metalloproteinase-1 in human prostate. J Urol 160: $1872-1876$

Hoang CD, D’Cunha J, Kratzke MG, Casmey CE, Frizelle SP, Maddaus MA Kratzke RA (2004) Gene expression profiling identifies matriptase overexpression in malignant mesothelioma. Chest 125: $1843-1852$

Holten-Andersen MN, Hansen U, Brunner N, Nielsen HJ, Illemann M, Nielsen BS (2005) Localization of tissue inhibitor of metalloproteinases 1 (TIMP-1) in human colorectal adenoma and adenocarcinoma. Int $J$ Cancer 113: $198-206$

Jiang Y, Goldberg ID, Shi YE (2002) Complex roles of tissue inhibitors of metalloproteinases in cancer. Oncogene 21: 2245-2252

Jiang Y, Wang M, Celiker MY, Liu YE, Sang QX, Goldberg ID, Shi YE (2001) Stimulation of mammary tumorigenesis by systemic tissue inhibitor of matrix metalloproteinase 4 gene delivery. Cancer Res 61: 2365-2370

Kalluri R (2003) Basement membranes: structure, assembly and role in tumour angiogenesis. Nat Rev Cancer 3: $422-433$

Klezovitch O, Chevillet J, Mirosevich J, Roberts RL, Matusik RJ, Vasioukhin $\mathrm{V}$ (2004) Hepsin promotes prostate cancer progression and metastasis. Cancer Cell 6: $185-195$

Kossakowska AE, Urbanski SJ, Janowska-Wieczorek A (2000) Matrix metalloproteinases and their tissue inhibitors - expression, role and regulation in human malignant non-Hodgkin's lymphomas. Leuk Lymphoma 39: 485-493

Kuittinen O, Apaja-Sarkkinen M, Turpeenniemi-Hujanen T (2003) Gelatinases (MMP-2 and MMP-9), TIMP-1 expression and the extent of neovascularization in aggressive non-Hodgkin's lymphomas. Eur J Haematol 71: $91-99$

Lafleur MA, Handsley MM, Edwards DR (2003) Metalloproteinases and their inhibitors in angiogenesis. Expert Rev Mol Med 22: 1-39

Lee SJ, Yoo HJ, Bae YS, Kim HJ, Lee ST (2003) TIMP-1 inhibits apoptosis in breast carcinoma cells via a pathway involving pertussis toxin-sensitive $\mathrm{G}$ protein and c-Src. Biochem Biophys Res Commun 312: 1196-1201

Lee SL, Dickson RB, Lin CY (2000) Activation of hepatocyte growth factor and urokinase/plasminogen activator by matriptase, an epithelial membrane serine protease. J Biol Chem 275: 36720-36725 
Levi F, Lucchini F, Negri E, Boyle P, La Vecchia C (2004) Cancer mortality in Europe, 1995-1999, and an overview of trends since 1960. Int J Cancer 110: $155-169$

Lichtinghagen R, Musholt PB, Lein M, Romer A, Rudolph B, Kristiansen G, Hauptmann S, Schnorr D, Loening SA, Jung K (2002) Different mRNA and protein expression of matrix metalloproteinases 2 and 9 and tissue inhibitor of metalloproteinases 1 in benign and malignant prostate tissue. Eur Urol 42: 398 - 406

Lin CY, Wang JK, Torri J, Dou L, Sang QA, Dickson RB (1997) Characterization of a novel, membrane-bound, $80-\mathrm{kDa}$ matrix-degrading protease from human breast cancer cells. Monoclonal antibody production, isolation, and localization. I Biol Chem 272: 9147-9152

Liu XW, Bernardo MM, Fridman R, Kim HR (2003) Tissue inhibitor of metalloproteinase-1 protects human breast epithelial cells against intrinsic apoptotic cell death via the focal adhesion kinase/phosphatidylinositol 3-kinase and MAPK signaling pathway. J Biol Chem 278: $40364-40372$

Llano E, Pendas AM, Freije JP, Nakano A, Knauper V, Murphy G, LopezOtin C (1999) Identification and characterization of human MT5-MMP, a new membrane-bound activator of progelatinase A overexpressed in brain tumors. Cancer Res 59: 2570-2576

Lokeshwar BL, Selzer MG, Block NL, Gunja-Smith Z (1993) Secretion of matrix metalloproteinases and their inhibitors (tissue inhibitor of metalloproteinases) by human prostate in explant cultures: reduced tissue inhibitor of metalloproteinase secretion by malignant tissues. Cancer Res 53: 4493 - 4498

Lopez-Otin C, Overall CM (2002) Protease degradomics: a new challenge for proteomics. Nat Rev Mol Cell Biol 3: 509-519

Marchenko GN, Ratnikov BI, Rozanov DV, Godzik A, Deryugina EI, Strongin AY (2001) Characterization of matrix metalloproteinase-26, a novel metalloproteinase widely expressed in cancer cells of epithelial origin. Biochem J 356: 705-718

Mathew R, Khanna R, Kumar R, Mathur M, Shukla NK, Ralhan R (2002) Stromelysin-2 overexpression in human esophageal squamous cell carcinoma: potential clinical implications. Cancer Detect Prev 26: $222-228$

McCabe NP, Angwafo III FF, Zaher A, Selman SH, Kouinche A, Jankun J (2000) Expression of soluble urokinase plasminogen activator receptor may be related to outcome in prostate cancer patients. Oncol Rep 7: 879-882

Miyake H, Hara I, Yamanaka K, Gohji K, Arakawa S, Kamidono S (1999) Elevation of serum levels of urokinase-type plasminogen activator and its receptor is associated with disease progression and prognosis in patients with prostate cancer. Prostate 39: 123 - 129

Morgia G, Falsaperla M, Malaponte G, Madonia M, Indelicato M, Travali S, Mazzarino MC (2005) Matrix metalloproteinases as diagnostic (MMP-13) and prognostic (MMP-2, MMP-9) markers of prostate cancer. Urol Res 33: $44-50$

Nie J, Pei D (2003) Direct activation of pro-matrix metalloproteinase-2 by leukolysin/membrane-type 6 matrix metalloproteinase/matrix metalloproteinase 25 at the asn(109)-Tyr bond. Cancer Res 63: 6758-6762

Nuttall RK, Pennington CJ, Taplin J, Wheal A, Yong VW, Forsyth PA, Edwards DR (2003) Elevated membrane-type matrix metalloproteinases in gliomas revealed by profiling proteases and inhibitors in human cancer cells. Mol Cancer Res 1: 333-345

Oberst M, Anders J, Xie B, Singh B, Ossandon M, Johnson M, Dickson RB, Lin CY (2001) Matriptase and HAI-1 are expressed by normal and malignant epithelial cells in vitro and in vivo. Am J Pathol 158: $1301-1311$

Oberst MD, Johnson MD, Dickson RB, Lin CY, Singh B, Stewart M, Williams A, al Nafussi A, Smyth JF, Gabra H, Sellar GC (2002) Expression of the serine protease matriptase and its inhibitor HAI-1 in epithelial ovarian cancer: correlation with clinical outcome and tumor clinicopathological parameters. Clin Cancer Res 8: 1101-1107

Oberst MD, Singh B, Ozdemirli M, Dickson RB, Johnson MD, Lin CY (2003) Characterization of matriptase expression in normal human tissues. $I$ Histochem Cytochem 51: 1017-1025

Oelmann E, Herbst H, Zuhlsdorf M, Albrecht O, Nolte A, Schmitmann C, Manzke O, Diehl V, Stein H, Berdel WE (2002) Tissue inhibitor of metalloproteinases 1 is an autocrine and paracrine survival factor, with additional immune-regulatory functions, expressed by Hodgkin/Reed Sternberg cells. Blood 99: 258-267

Oh J, Takahashi R, Kondo S, Mizoguchi A, Adachi E, Sasahara RM, Nishimura S, Imamura Y, Kitayama H, Alexander DB, Ide C, Horan TP, Arakawa $\mathrm{T}$, Yoshida $\mathrm{H}$, Nishikawa $\mathrm{S}$, Itoh $\mathrm{Y}$, Seiki $\mathrm{M}$, Itohara $\mathrm{S}$,
Takahashi C, Noda M (2001) The membrane-anchored MMP inhibitor RECK is a key regulator of extracellular matrix integrity and angiogenesis. Cell 107: 789-800

Pajouh MS, Nagle RB, Breathnach R, Finch JS, Brawer MK, Bowden GT (1991) Expression of metalloproteinase genes in human prostate cancer. J Cancer Res Clin Oncol 117: 144-150

Pedersen AN, Christensen IJ, Stephens RW, Briand P, Mouridsen HT, Dano $\mathrm{K}$, Brunner N (2000) The complex between urokinase and its type-1 inhibitor in primary breast cancer: relation to survival. Cancer Res 60: 6927-6934

Porter JF, Shen S, Denhardt DT (2004) Tissue inhibitor of metalloproteinase-1 stimulates proliferation of human cancer cells by inhibiting a metalloproteinase. $\mathrm{Br} J$ Cancer 90: 463-470

Qi JH, Ebrahem Q, Moore N, Murphy G, Claesson-Welsh L, Bond M, Baker A, Anand-Apte B (2003) A novel function for tissue inhibitor of metalloproteinases-3 (TIMP3): inhibition of angiogenesis by blockage of VEGF binding to VEGF receptor-2. Nat Med 9: 407-415

Rhee JS, Diaz R, Korets L, Hodgson JG, Coussens LM (2004) TIMP-1 alters susceptibility to carcinogenesis. Cancer Res 64: 952-961

Riddick AC, Barker C, Sheriffs I, Bass R, Ellis V, Sethia KK, Edwards DR, Ball RY (2003) Banking of fresh-frozen prostate tissue: methods, validation and use. BJU Int 91: $315-323$

Robert C, Bolon I, Gazzeri S, Veyrenc S, Brambilla C, Brambilla E (1999) Expression of plasminogen activator inhibitors 1 and 2 in lung cancer and their role in tumor progression. Clin Cancer Res 5: 2094-2102

Salden M, Splinter TA, Peters HA, Look MP, Timmermans M, van Meerbeeck JP, Foekens JA (2000) The urokinase-type plasminogen activator system in resected non-small-cell lung cancer. Rotterdam Oncology Thoracic Study Group. Ann Oncol 11: 327-332

Sasahara RM, Brochado SM, Takahashi C, Oh J, Maria-Engler SS, Granjeiro JM, Noda M, Sogayar MC (2002) Transcriptional control of the RECK metastasis/angiogenesis suppressor gene. Cancer Detect Prev 26: $435-443$

Srikantan V, Valladares M, Rhim JS, Moul JW, Srivastava S (2002) HEPSIN inhibits cell growth/invasion in prostate cancer cells. Cancer Res 62: $6812-6816$

Stamey TA, Warrington JA, Caldwell MC, Chen Z, Fan Z, Mahadevappa M, McNeal JE, Nolley R, Zhang Z (2001) Molecular genetic profiling of Gleason grade $4 / 5$ prostate cancers compared to benign prostatic hyperplasia. J Urol 166: $2171-2177$

Stephan C, Yousef GM, Scorilas A, Jung K, Jung M, Kristiansen G, Hauptmann S, Kishi T, Nakamura T, Loening SA, Diamandis EP (2004) Hepsin is highly over expressed in and a new candidate for a prognostic indicator in prostate cancer. J Urol 171: 187-191

Sternlicht MD, Werb Z (2001) How matrix metalloproteinases regulate cell behavior. Annu Rev Cell Dev Biol 17: 463-516

Still K, Robson CN, Autzen P, Robinson MC, Hamdy FC (2000) Localization and quantification of mRNA for matrix metalloproteinase-2 (MMP-2) and tissue inhibitor of matrix metalloproteinase-2 (TIMP-2) in human benign and malignant prostatic tissue. Prostate 42: 18-25

Takeuchi T, Shuman MA, Craik CS (1999) Reverse biochemistry: use of macromolecular protease inhibitors to dissect complex biological processes and identify a membrane-type serine protease in epithelial cancer and normal tissue. Proc Natl Acad Sci USA 96: 11054-11061

Thorns V, Walter GF, Thorns C (2003) Expression of MMP-2, MMP-7, MMP-9, MMP-10 and MMP-11 in human astrocytic and oligodendroglial gliomas. Anticancer Res 23: 3937 - 3944

Trudel D, Fradet Y, Meyer F, Harel F, Tetu B (2003) Significance of MMP-2 expression in prostate cancer: an immunohistochemical study. Cancer Res 63: $8511-8515$

Tunuguntla R, Ripley D, Sang QX, Chegini N (2003) Expression of matrix metalloproteinase-26 and tissue inhibitors of metalloproteinases TIMP-3 and -4 in benign endometrium and endometrial cancer. Gynecol Oncol 89: $453-459$

Udayakumar TS, Chen ML, Bair EL, Von Bredow DC, Cress AE, Nagle RB, Bowden GT (2003) Membrane type-1-matrix metalloproteinase expressed by prostate carcinoma cells cleaves human laminin-5 beta3 chain and induces cell migration. Cancer Res 63: 2292-2299

Van Themsche C, Alain T, Kossakowska AE, Urbanski S, Potworowski EF, St Pierre Y (2004) Stromelysin-2 (matrix metalloproteinase 10) is inducible in lymphoma cells and accelerates the growth of lymphoid tumors in vivo. J Immunol 173: 3605-3611

Wall SJ, Edwards DR (2002) Quantitative reverse transcription-polymerase chain reaction (RT-PCR): a comparison of primer-dropping, competitive and real-time RT - PCRs. Anal Biochem 300: 269-273 
Wang M, Liu YE, Greene J, Sheng S, Fuchs A, Rosen EM, Shi YE (1997) Inhibition of tumor growth and metastasis of human breast cancer cells transfected with tissue inhibitor of metalloproteinase 4. Oncogene 14: $2767-2774$

Wood M, Fudge K, Mohler JL, Frost AR, Garcia F, Wang M, Stearns ME (1997) In situ hybridization studies of metalloproteinases 2 and 9 and TIMP-1 and TIMP-2 expression in human prostate cancer. Clin Exp Metastasis 15: 246-258

Yamanaka M, Watanabe M, Yamada Y, Takagi A, Murata T, Takahashi H, Suzuki H, Ito H, Tsukino H, Katoh T, Sugimura Y, Shiraishi T (2003) Altered methylation of multiple genes in carcinogenesis of the prostate. Int J Cancer 106: $382-387$
You X, Yu HM, Cohen-Gould L, Cao B, Symons M, Vande Woude GF, Knudsen BS (2003) Regulation of migration of primary prostate epithelial cells by secreted factors from prostate stromal cells. Exp Cell Res 288: 246-256

Zhao YG, Xiao AZ, Newcomer RG, Park HI, Kang T, Chung LW, Swanson MG, Zhau HE, Kurhanewicz J, Sang QX (2003) Activation of progelatinase B by endometase/matrilysin-2 promotes invasion of human prostate cancer cells. J Biol Chem 278: $15056-15064$

Zhao YG, Xiao AZ, Park HI, Newcomer RG, Yan M, Man YG, Heffelfinger SC, Sang QX (2004) Endometase/matrilysin-2 in human breast ductal carcinoma in situ and its inhibition by tissue inhibitors of metalloproteinases- 2 and -4 : a putative role in the initiation of breast cancer invasion. Cancer Res 64: 590-598 